\title{
Uji Aktivitas Ekstrak Etanol Kulit Durian (Durio zibethinus Murr.) terhadap Bakteri Propionibacterium acnes dan Staphylococcus aureus
}

\author{
Safitri, A.T., Nur Adiratna, N., Drajat S., Ismail \\ Sekolah Tinggi Ilmu Farmasi Makassar \\ Jl.Perintis Kemerdekaan Km 13,7 Daya, Makassar, Sulawesi Selatan, 90241 \\ Email: anditendrianisafitri4@gmail.com
}

Riwayat artikel: Dikirim: 24/01/2020; Diterima: 06/07/2020, Diterbitkan: 27/12/2020

\begin{abstract}
Durian peel (Durio zibethinus Murr) is a plant that can be used as a treatment. Durian skin contains secondary metabolites, namely flavonoids which have antibacterial activity. The bacteria that cause acne are Propionibacterium acnes and Staphylococcus aureus. The extract was obtained by maceration using $70 \%$ ethanol solvent. The ethanol extract of durian peel obtained was made in 3 series of concentrations of $10 \%$, $15 \%$ and $25 \%$ then tested on propionibacterium acnes and staphylococcus aureus bacteria. The MIC value of Propionibacterium acnes bacteria obtained was $10 \%$ with an area of inhibition zone formed of $7.5 \mathrm{~mm} \pm 0.4$ $\mathrm{mm} .15 \%$ with an area of inhibition zone formed of $7.7 \mathrm{~mm} \pm 0.3 \mathrm{~mm} .25 \%$ with an area of inhibition zone formed of $8.4 \mathrm{~mm} \pm 0.2 \mathrm{~mm}$ while the MIC value of the Staphylococcus aureus bacteria obtained was $10 \%$ with an area of inhibition zone formed of $8.11 \mathrm{~mm} \pm 0.4 \mathrm{~mm} .15 \%$ with an area of inhibition zone formed of $8.11 \mathrm{~mm} \pm 0.3 \mathrm{~mm} .25 \%$ with an area of inhibition zone formed of $8.8 \mathrm{~mm} \pm 0.5 \mathrm{~mm}$. based on the results of ethanol extract durian skin has activity against Propionibacterium acnes and Staphylococcus aureus.
\end{abstract}

Keywords: Durio zibethinus Murr, Acne, Propionibacterium acnes, Staphylococcus aureus

\begin{abstract}
ABSTRAK
Kulit durian (Durio zibethinus Murr) merupakan tanaman yang dapat digunakan sebagai pengobatan. Kulit durian memiliki kandungan metabolit sekunder yaitu flavonoid yang memiliki aktivitas sebagai antibakteri. Bakteri yang menjadi penyebab terjadinya jerawat adalah Propionibacterium acnes dan Staphylococcus aureus. Ekstrak diperoleh dengan cara maserasi menggunakan pelarut etanol $70 \%$. Ekstrak etanol kulit durian yang diperoleh dibuat dalam 3 seri konsentrasi 10\%, 15\% dan $25 \%$ kemudian diujikan pada bakteri propionibacterium acnes dan staphylococcus aureus. Nilai KHM pada bakteri Propionibacterium acnes yang diperoleh adalah $10 \%$ dengan luas zona hambat yang terbentuk sebesar 7,5 $\mathrm{mm} \pm 0,4 \mathrm{~mm} .15 \%$ dengan luas zona hambat yang terbentuk sebesar 7,7 $\mathrm{mm} \pm 0,3 \mathrm{~mm}$. 25\% dengan luas zona hambat yang terbentuk sebesar $8,4 \mathrm{~mm} \pm 0,2 \mathrm{~mm}$ sedangkan Nilai KHM pada bakteri Staphylococcus aureus yang diperoleh adalah $10 \%$ dengan luas zona hambat yang terbentuk sebesar $8,11 \mathrm{~mm} \pm 0,4 \mathrm{~mm}$. $15 \%$ dengan luas zona hambat yang terbentuk sebesar $8,11 \mathrm{~mm} \pm 0,3 \mathrm{~mm}$. $25 \%$ dengan luas zona hambat yang terbentuk sebesar $8,8 \mathrm{~mm} \pm 0,5 \mathrm{~mm}$. berdasarkan hasil penelitian ekstrak etanol kulit durian memiliki aktivitas terhadap Propionibacterium acnes dan Staphylococcus aureus.
\end{abstract}

Kata kunci: Durio zibethinus Murr, Acne, Propionibacterium acnes, Staphylococcus aureus

\section{PENDAHULUAN}

Jerawat merupakan penyakit folikel kelenjar lemak sebasea kulit dimana terjadi penyumbatan aliran sebum. Pada jerawat timbul komedo, papula, postula, nodula dan kista serta scar atau jaringan parut. Penyebab terjadinya kelenjar yaitu sebasea yang hiperaktif (sekresi 
DOI : https://doi.org/10.24843/JFU.2020.v09.i02.p01

pISSN: 2301-7716; eISSN: 2622-4607

Jurnal Farmasi Udayana, Vol 9, No 2, Tahun 2020, 66-71

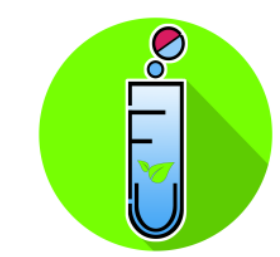

sebum yang terlalu hiperaktif), hiperkatosis (percepatan keratinasi) pada infundibulum rambut dan efek dari bakteri (Lismayanti, 2017). Penyebab jerawat sangat banyak antara lain genetik, faktor makanan, infeksi oleh Propionibacterium acnes, kosmetik, dan bahan kimia lainnya (Mitsui T., 1997).

Propionibacterium acnes adalah organisme utama yang pada umumnya memberi kontribusi terhadap terjadinya jerawat. Propionibacterium acnesadalah termasuk bakteri gram-positif berbentuk batang tidak berspora, tangkai anaerob ditemukan dalam spesimen-spesimen klinis, beberapa strain/jenis adalah aerotoleran, tetapi tetap menunjukkan pertumbuhan lebih baik sebagai anaerob aerotolerant (Brooks, dkk., 2005).

Penggunaan bahan tradisional oleh masyarakat Indonesia telah banyak digunakan dalam bentuk yang sederhana. Namun, seiring dengan perkembangan ilmu farmasi, bahan tradisional telah diformulasikan dalam bentuk sediaan seperti sediaan gel dengan terlebih dahulu mengekstraksi zat aktif yang terkandung dalam tanaman tersebut. Salah satu alasan dalam penggunaan bahan alam dalam membuat suatu sediaan yaitu memiliki efek samping yang sangat kecil jika dibandingkan dengan bahan sintetik (Mitsui T.,1997). Salah satu bahan alam yang sudah dibuktikan dapat memberikan khasiat atau aktivitas dalam menghambat bakteri Propionibacterium acnes yaitu kulit durian (Durio zibethinus Murr).

Berdasarkan (Courtney dkk., 2016) kulit durian mengandung senyawa golongan flavonoid, fenolik, alkaloid, steroid, saponin dan sedikit senyawa golongan terpenoid. Berdasarkan urain di atas dilakukan pengujian aktivitas ekstrak etanol kulit durian untuk mengetahui aktivitasi ekstrak dalam penghabatan pertumbuhan Propionibacterium acnes dan Staphylococcus aureus yang baik.

\section{BAHAN DAN METODE}

\subsection{Bahan dan Alat}

Bahan yang digunakan pada penelitian ini yaitu aluminium foil, aquadest, bakteri uji Propionibacterium acnes, bakteri uji Staphylococcus aureus kulit durian, etanol 70\%, $\mathrm{FeCl}_{3}, \mathrm{H}_{2} \mathrm{SO}_{4}$, kertas saring, kloroform, $\mathrm{NaCl}$ fisiologis $0,9 \%$, media nutrient agar dan tissue.

Alat yang digunakan pada penelitian ini yaitu autoklaf, cawan petri, cawan porselen, climatic chamber, erlenmeyer, fresh drayer, gelas ukur, homogenaizer $\quad\left(\right.$ WiseStir $^{\circledR}$ ), inkubator, jarum ose, lampu spritus, mortir dan stamfer, penangas air $\left(\right.$ Memmert $\left.^{\circledR}\right)$, pHmeter $\left(\right.$ Hanna $\left.^{\circledR}\right)$, pencadang, pinset, Rotavapor, seperangkat alat uji daya lekat, seperangkat alat uji daya sebar, spektrofotometri, timbangan analitik (Mettler Toledo $\left.{ }^{\circledR}\right)$, toples dan viscometer (Brookfield ${ }^{\circledR}$ ).

\subsection{Metode}

\subsubsection{Pengambilan Sampel}

Sampel yang digunakan dalam penelitian ini adalah kulit durian (Durio zibethinus Murr.) yang diambil di kecamatan Biringkanaya Sulawei Selatan.

\subsubsection{Pembuatan Simplisia}

Sampel berupa kulit durian yang digunakan disortasi basah, dicuci dengan air mengalir. Kulit durian yng telah dicuci kemudian dirajang,dikeringkan pada oven $\pm 50^{\circ} \mathrm{C}$. Setelah itu simplisia disortasi kering, kemudian diekstraksi dengan metode maserasi.

\subsubsection{Ekstraksi}

Ekstrak kulit durian diperoleh dengan cara maserasi. Sebanyak 500 gram simplisia kulit durian dimaserasi dengan cairan penyari etanol $70 \%$ sebanyak 5L, dibiarkan selama 3-5 hari sambil sesekali diaduk. Setelah proses ekstraksi 
DOI : https://doi.org/10.24843/JFU.2020.v09.i02.p01

pISSN: 2301-7716; eISSN: 2622-4607

Jurnal Farmasi Udayana, Vol 9, No 2, Tahun 2020, 66-71

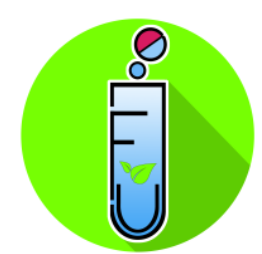

pertama filtratnya disaring kemudian ampasnya diremaserasi kembali dengan cara yang sama. Ekstrak cair yang telah dikumpulkan lalu diuapkan hingga diperoleh ekstrak kental. Ekstrak disimpan dalam wadah tertutup sebelum digunakan untuk pengujian selanjutnya.

\subsubsection{Skrining Fitokimia}

\section{a. Uji Tanin}

Ekstrak diteteskan di atas pelat tetes dan ditambah larutan $\mathrm{FeCl}_{3} 1 \%$. Hasil positif ditandai dengan perubahan warna larutan menjadi biru atau hitam kehijauan.

\section{b. Uji Alkaloid}

Ekstrak ditambah kloroform dan asam sulfat secara berurutan kemudian dikocok. Larutan didiamkan hingga kloroform dan asam sulfat memisah. Lapisan asam (bagian atas) diteteskan pada pelat tetes dan diuji dengan reagen Wagner (kalium tetraidomerkurat) dan reagen Dragendorff (kalium tetraidobismutat). Hasil positif ditandai dengan terbentuknya endapan coklat kemerahan pada reagen Dragendorff dan warna coklat pada reagen Wagner.

\section{c. Uji Triterpenoid dan Saponin}

Ekstrak ditambah kloroform dan dikocok kuat-kuat. Terbentuknya busa yang stabil selama 30 menit. Ekstrak yang sudah ditambah dengan kloroform, ditambah dengan asam klorida $2 \mathrm{~N}$ kemudian disaring. Lapisan atas diuji dengan reagen Liebeman Bouchard. Hasil positif triterpenoid ditandai dengan terbentuknya warna merah.

\section{d. Uji Flavonoid}

Ekstrak ditambah serbuk $\mathrm{Mg}$ dan $1 \mathrm{~mL}$ $\mathrm{HCl}$ pekat, selanjutnya ditambah amyl alkohol, kocok dengan kuat dan dibiarkan terpisah.
Terbentuknya warna jingga dalam lapisan amyl alkohol menunjukkan adanya flavonoid.

\subsubsection{Sterilisasi Alat}

Alat-alat yang digunakan disterilkan terlebih dahulu, untuk alat-alat yang bersifat tahan panas dan terbuat dari kaca disterilkan dengan menggunakan oven pada $170^{\circ} \mathrm{C}$ selama 2 jam sedangkan untuk alat-alat plastik dan berskala disterilkan di autoklaf pada suhu $121^{\circ} \mathrm{C}$ selama 15 menit. Alat-alat logam disterilkan dengan cara dipijarkan dengan menggunakan lampu spiritus.

\subsubsection{Peremajaan Kutur Murni Bakteri Uji}

Bakteri uji berupa Propionibacterium acnes dan Staphyloccus aureus. Stok biakan murni diambil menggunakan swab sterik1 kemudian diinokulasi dengan cara menggoreskan pada medium MHA, kemudian diinkubasi pada suhu $37^{\circ} \mathrm{C}$ selama $1 \times 24$ jam. Setelah itu bakteri dapat digunakan sebagai mikroba uji.

\subsubsection{Pembuatan Suspensi Kultur Murni}

Sebanyak 1 ose bakteri uji hasil peremajaan, disuspensikan dalam $1 \mathrm{~mL} \mathrm{NaCl}$ fisiologis dalam tabung reaksi steril kemudian kekeruhannya dilihat dengan membandingkan kekeruhan standar 0,5 Mc Farland (setara dengan $\left.3 \times 10^{8} \mathrm{CFU} / \mathrm{MI}\right)$

\subsubsection{Penyiapan Sampel Uji}

Ekstrak etanol kulit durian dibuat dengan tiga konsentrasi yaitu 1\%, 3\%, 5\% dengan cara ditimbang 0,01 g, 0,03 g, dan 0,07 g ekstrak etanol kulit durian kemudian masing- masing dilarutkan dalam $1 \mathrm{~mL}$ aqua pro injeksi. 
2.2.8 Pengujian Aktivitas Ekstrak Etanol Kulit Durian

Pengujian aktivitas ekstak etanol kulit durian terhadap pertumbuhan bakteri Propionibacterium acnes dan Staphylococcus aureus dilakukan dengan meode difusi agar dengan menggunakan medium MHA. Medium MHA dituang kedalam cawan petri steril sebanyak $\mathrm{mL}$ kemudian dibiarkan memadat Setelah medium memadat suspensi bakteri digoreskan menggunakan swab steril pada permukaan medium kemudian dimasukkan paper disk yang telah ditetesi $20 \mu l$ dengan ekstrak etanol kulit durian 1\%, 3\% dan 5\% sedangkan untuk kontrol negatif digunakan aquadest steril Kontrol positif digunakan 1000 $\mu l$ clindamicyn yang kemudian diatur sedemikian rupa jaraknya. Kemudian diinkubasi secara anaerob pada suhu $37^{\circ} \mathrm{C}$ selama $1 \times 24$ jam. Diamati zona bening dan diukur diameter daerah hambatnya dengan jangka sorong. Pengujian ini diambil sebanyak 3 kali diambil rata-ratanya.

\section{HASIL}

Tabel 1. Hasil Skrining Fitokimia

\begin{tabular}{llll}
\hline Senyawa Uji & Pereaksi & Hasil Uji & Ket \\
\hline Alkaloid & Kloroform $+\mathrm{H}_{2} \mathrm{SO}_{4}$ & Coklat Kemerahan & \\
& + Reagent Wagner & Coklat & \\
& + Reagent Dragendroff & Terbentuk Busa & Positif \\
Saponin & Kloroform Dikocok Kuat & Larutan Merah & Positif \\
Flavonoid & Serbuk $\mathrm{Mg}+\mathrm{Hcl}$ Pekat + Amyl Alkohol & & Positif \\
& & Biru & \\
Tanin & $\mathrm{FeCl}_{3}$ & & \\
\hline
\end{tabular}

Tabel 2. Hasil Uji Aktivitas

\begin{tabular}{cccccc}
\hline \multirow{2}{*}{ Bakteri Uji } & \multicolumn{2}{c}{ Diameter zona hambat $\mathbf{( m m )}$} & \multicolumn{2}{c}{ Kontrol } & Positif \\
& $\mathbf{1 0 \%}$ & $\mathbf{1 5 \%}$ & $\mathbf{2 5 \%}$ & (Clindamicyn) & $\begin{array}{c}\text { Negatif } \\
\text { (Aquadest) }\end{array}$ \\
\hline Propionibacterium acnes & $7,5 \pm 0,4$ & $7,7 \pm 0,3$ & $8,4 \pm 0,2$ & $25,5 \pm 0,3$ & $6,8 \pm 0,6$ \\
Staphylococcus aureus & $8,11 \pm 0,4$ & $8,11 \pm 0,3$ & $8,8 \pm 0,5$ & $25,2 \pm 0,1$ & $8,01 \pm 0,7$ \\
\hline
\end{tabular}

\section{PEMBAHASAN}

Kandungan senyawa yang terdapat dalam ekstrak etanol kulit durian diantaranya flavonoid memberikan respon hambatan dengan mengganggu keutuhan membran sel bakteri oleh adanya pembentukan senyawa kompleks dari protein ekstraseluler dengan flavonoid (Kumar \& Pandey, 2013). Tanin sebagai antibakteri bekerja berdasarkan kemampuannya mempresipitasi protein, karena tanin mempunyai efek yang sama dengan fenolik (Courtney dkk., 2016).

Aktivitas saponin sebagai antibakteri ditunjukkan oleh mekanisme penurunan tegangan permukaan dinding sel bakteri.
Akibatnya sel bakteri akan mengalami kebocoran sehingga mengakibatkan kematian sel (Ngajow dkk., 2013). Steroid dilaporkan memiliki sifat antibakteri, korelasi antara membran lipid dan sensitivitas senyawa steroid menunjukkan mekanisme dimana steroid menyebabkan kebocoran liposom (Shihabudeen dkk., 2010).

Berdasarkan hasil orientasi Nilai KHM pada bakteri Propionibacterium acnes yang diperoleh adalah $10 \%$ dengan luas zona hambat yang terbentuk sebesar 7,5 $\mathrm{mm} \pm 0,4 \mathrm{~mm}$. $15 \%$ dengan luas zona hambat yang terbentuk sebesar $7,7 \mathrm{~mm} \pm 0,3 \mathrm{~mm}$. $25 \%$ dengan luas zona hambat yang terbentuk sebesar $8,4 \mathrm{~mm} \pm$ $0,2 \mathrm{~mm}$ sedangkan Nilai KHM pada bakteri 
DOI : https://doi.org/10.24843/JFU.2020.v09.i02.p01

pISSN: 2301-7716; eISSN: 2622-4607

Jurnal Farmasi Udayana, Vol 9, No 2, Tahun 2020, 66-71

Staphylococcus aureus yang diperoleh adalah $10 \%$ dengan luas zona hambat yang terbentuk sebesar $8,11 \mathrm{~mm} \pm 0,4 \mathrm{~mm}$. $15 \%$ dengan luas zona hambat yang terbentuk sebesar $8,11 \mathrm{~mm} \pm$ $0,3 \mathrm{~mm}$. $25 \%$ dengan luas zona hambat yang terbentuk sebesar $8,8 \mathrm{~mm} \pm 0,5 \mathrm{~mm}$ termasuk kategori sedang karena diameter zona hambatnya masuk dalam rentang 5-10 (David \& Stout, 1971). Menurut Jawetz dkk. (2005), kinerja senyawa antibakteri dipengaruhi oleh struktur dinding sel bakteri. Pelczar dan Chan (2005) menyatakan struktur dinding sel bakteri gram negatif relatif lebih kompleks karena tersusun dari tiga lapisan, yaitu lipoprotein, lipopolisakarida, dan peptidoglikan sehingga ketahanan senyawa antimikroba terhadap Escherichia coli lebih baik dibandingkan dengan bakteri gram positif. Klindamisin sebagai kontrol positif mempunyai rata-rata diameter zona hambat sebesar 25,5 $\mathrm{mm} \pm 0,3 \mathrm{~mm}$ terhadap bakteri Propionibacterium acne dan 25,2 \pm 0,1 mm terhadap bakter Staphylococcus aureus artinya respon hambatan dari kontrol positif termasuk kategori kuat. Klindamisin digunakan sebagai kontrol positif karena aktivitas antibakteri klindamisin sama halnya yang ditunjukkan pada senyawa kimia yang terkandung dalam Zibethinus folium. Menurut Katzung dkk.(2012), klindamisin bekerja dengan meghambat sintesis protein.

Berdasarkan hasil diameter zona hambat yang terdapat pada tabel diatas dapat disimpulkan bahwa semakin tinggi konsentrasi ekstrak maka semakin besar zona hambat yang terbentuk. Berdasarkan hasil pengujian yang diperoleh maka dapat diketahui bahwa ekstrak kulit durian mampu menghambat bakteri Propionibacterium acne dan Staphylococcus aureus.

\section{KESIMPULAN}

Adapun hasil dari penelitian yang diperoleh dapat ditarik kesimpulan bahwa ekstrak etanol kulit durian dapat menghambat pertumbuhan Propionibacterium acne dan Staphylococcus aureus dengan baik.

\section{UCAPAN TERIMAKASIH}

Penulis mengucapkan terima kasih kepada RISTEKDIKTI yang telah memberikan bantuan dana untuk pelaksanaan penelitian ini dan Sekolah Tinggi Ilmu Farmasi Makassar yang telah memberikan bantuan teknis meliputi alat, bahan serta sarana prasarana penunjang selama penelitian berlangsung.

\section{DAFTAR PUSTAKA}

1. Brooks G.F., Janet S.B. and Stephen A.M., 2005, Mikrobiologi Kedokteran, Dalam Mudihardi, E. et al., eds. Jawetz, Melnick and Adelberg's, Penerbit Salemba Medika, Jakarta

2. Courtney, R., Sirdaarta, J., Matthews, B. \& Cock, I.E., 2016. Tannin Components and Inhibitory Activity of Kakadu Plum Leaf Extracts Against Microbial Triggers of Autoimmune Inflammatory Diseases. Pharmacognosy Journal, 7(1), pp.18-31

3. David, W.W. and Stout, T.R. 1971. Disc Plate Method of Microbiological Antibiotic Assay. Microbiology. 22(4): 659-665.

4. Jawetz, Melnick \& Adelberg's, 2005. Mikrobiologi Kedokteran. Jakarta : Salemba Medika. Hal: 233, 235.

5. Katzung, B.G., Masters, S.B. \& Trevor, A.J., 2012. Basic \& Clinical Pharmacology. 12th Ed. United States: McGraw-Hill Companies.

6. Kumar, S. \& Pandey, A.K., 2013. Chemistry and Biological Activities of Flavonoids: An Overview. The ScientificWorld Journal, 29, pp.1-16.

7. Lismayanti Et Al. - 2017 - Pengujian Aktivitas Antibakteri Ekstrak Bertingkat.Pdf, N.D.

8. Mitsui T., 1997, New Cosmetic Science, Dalam Elsevier Science B.V., Amsterdam.

9. Ngajow, M., Abidjulu, J. \& Kamu, V.S., 2013. Pengaruh Antibakteri Ekstrak Kulit 
Safitri, dkk.

DOI : https://doi.org/10.24843/JFU.2020.v09.i02.p01

pISSN: 2301-7716; eISSN: 2622-4607

Jurnal Farmasi Udayana, Vol 9, No 2, Tahun 2020, 66-71

Batang Matoa (Pometia pinnata) terhadap 11. Shihabudeen, M.S., H, H.P.D. \& Bakteri Staphylococcus aureussecara Invitro. Jurnal MIPA UNSTRAT, 2(2), pp.128-32

Thirumurugan, K., 2010. Antimicrobial Activity and Phytochemical Analysis of

10. Pelczar Michael J. \&Chan E.C.S. 2005.

Dasar-Dasar Mikrobiologi 1. Jakarta: UI Press. Hal: 711-712 dan 867-868

Selected Indian Folk Medicinal Plants. International Journal of Pharma Sciences and Research, 1(10), pp.430-34.

This work is licensed under a Creative Commons Attribution 4.0 International License 